\title{
Country governance and the performance of Islamic and conventional bank: international evidence
}

\begin{abstract}
The impact of corporate governance on banking firms has been widely documented in the literature. Noticeably absent is an extensive examination of the impact of country governance on the efficiency of banking firms. This limitation is surprising, given the fact that the banking sector remains the most important channel for savings and allocations of credit in the economy. By using data on 454 Islamic and conventional banks from 19 countries offering Islamic banking and finance products and services, this chapter attempts to fill this demanding gap. We find that voice and accountability positively influence the efficiency of both Islamic and conventional banks. On the other hand, we observe the negative impact of political stability, absence of violence and control of corruption. The findings indicate that government effectiveness, regulatory quality and rule of law negatively influence the efficiency of conventional banks, but not so in the case of Islamic banks.
\end{abstract}

